\title{
Thyroid hormone-stimulated differentiation of primary rib chondrocytes in vitro requires thyroid hormone receptor $\beta$
}

\author{
Bénédicte Rabier ${ }^{1,2}$, Allan J Williams ${ }^{3}$, Frederic Mallein-Gerin ${ }^{4}$, Graham R Williams ${ }^{3}$ and O Chassande ${ }^{1,2}$ \\ ${ }^{1}$ INSERM U577-Biomatériaux et Réparation Tissulaire, Université Bordeaux 2 Victor Segalen, Zone Nord, Bâtiment 4A, 2ème étage, 33076 Bordeaux Cedex, \\ France \\ ${ }^{2}$ Université Victor Segalen Bordeaux 2, Bordeaux, France \\ ${ }^{3}$ Molecular Endocrinology Group, Division of Medicine, Faculty of Medicine, MRC Clinical Sciences Centre, Imperial College London, Hammersmith Hospital, \\ Du Cane Road, London W12 0NN, UK \\ ${ }^{4}$ Laboratoire de Biologie et Ingénierie du Cartilage, Institut de Biologie et Chimie des Protéines, UMR 5086 CNRS/UCBLyon 1, 7 passage du Vercors, 69367 Lyon \\ Cedex 07, France
}

(Requests for offprints should be addressed to O Chassande; Email: chassande@bordeaux.inserm.fr)

\begin{abstract}
The active thyroid hormone, triiodothyronine $\left(\mathrm{T}_{3}\right)$, binds to thyroid hormone receptors (TR) and plays an essential role in the control of chondrocyte proliferation and differentiation. Hypo- and hyperthyroidism alter the structure of growth plate cartilage and modify chondrocyte gene expression in vivo, whilst TR mutations or deletions in mice result in altered growth plate architecture. Nevertheless, the particular roles of individual $\mathrm{TR}$ isoforms in mediating $\mathrm{T}_{3}$ action in chondrocytes have not been studied and are difficult to determine in vivo because of complex cellular and molecular interactions that regulate growth plate maturation. Therefore, we studied the effects of $\operatorname{TR} \alpha$ and $\operatorname{TR} \beta$ on chondrocyte growth and

differentiation in primary cultures of neonatal rib chondrocytes isolated from TR $\alpha$ - and TR $\beta$-deficient mice. $T_{3}$ decreased proliferation but accelerated differentiation of rib chondrocytes from wild-type mice. $T_{3}$ treatment resulted in similar effects in TR $\alpha$-deficient chondrocytes, but in TR $\beta$ deficient chondrocytes, all $T_{3}$ responses were abrogated. Furthermore, $T_{3}$ increased TR $\beta 1$ expression in wild-type and TR $\alpha$-deficient chondrocytes. These data indicate that $\mathrm{T}_{3}$-stimulated differentiation of primary rib chondrocytes in vitro requires $\operatorname{TR} \beta$ and suggest that the TR $\beta 1$ isoform mediates important $T_{3}$ actions in mouse rib chondrocytes.

Journal of Endocrinology (2006) 191, 221-228
\end{abstract}

\section{Introduction}

Triiodothyronine $\left(T_{3}\right)$ plays a key role in bone growth and maturation (Bassett \& Williams 2003). Hypothyroidism results in growth retardation, epiphyseal dysgenesis and delayed bone mineralization. In contrast, thyrotoxicosis accelerates growth and advances bone age, but causes short stature due to early closure of the growth plates. Longitudinal growth results from proliferation of growth plate chondrocytes, differentiation of proliferating chondrocytes and enlargement of hypertrophic chondrocytes, which increase their volume by tenfold during maturation. Hypertrophic chondrocytes also play a key role in the control of bone vascularization and thus regulate endochondral ossification (Gerber \& Ferrara 2000, Goldring et al. 2006).

Both hypothyroidism and thyrotoxicosis alter the structure and organization of the growth plate in vivo (Lewinson et al. 1994, Stevens et al. 2000, Freitas et al. 2005). Hypothyroidism increases the width of the proliferative zone but reduces the size of the hypertrophic zone. In contrast, thyrotoxicosis results in a reduced width of both proliferative and hypertrophic zones. Nevertheless, the mechanisms by which altered thyroid status regulates the growth plate remain unclear. In vivo, thyroid hormones regulate expression of parathyroid hormone related peptide $(\mathrm{PTHrP})$ and $\mathrm{PTHrP}$ receptors, which control the pace of chondrocyte proliferation during endochondral ossification (Stevens et al. 2000). In organ cultures, thyroxine $\left(T_{4}\right)$ is a potent stimulator of chondrocyte differentiation (Wakita et al. 1998, Miura et al. 2002), whilst in vitro $\mathrm{T}_{3}$ decreases the growth of chondrocyte colonies and inhibits cell proliferation (Bohme et al. 1992, Ohlsson et al. 1992, Robson et al. 2000, Okubo \& Reddi 2003). Many investigators have also demonstrated a positive role for $\mathrm{T}_{3}$ in regulating terminal differentiation of chondrocytes in vitro in several species using different culture systems (Ohlsson et al. 1992, Quarto et al. 1992, Ballock \& Reddi 1994, Bohme et al. 1995, Alini et al. 1996, Leboy et al. 1997, Ishikawa et al. 1998, Okubo \& Reddi 2003). Mechanistic studies have revealed that thyroid hormone $(\mathrm{TH})$ stimulates expression of $\mathrm{p} 21$, a cyclin D1 inhibitor, in rat epiphyseal chondrocytes in vitro (Ballock et al. 2000) and inhibits the expression of Sox-9, a transcription factor that maintains chondrocytes in an undifferentiated state, in mouse rib chondrocytes (Okubo \& Reddi 2003). Furthermore, $T_{3}$ stimulates fibroblast growth factor (FGF) receptor expression 
in ATDC5 cells and enhances FGF signalling in these cells and also in primary mouse rib chondrocytes (Barnard et al. 2005). However, precisely how these responses are involved in the $\mathrm{T}_{3}$ control of chondrocyte proliferation and differentiation has not been determined.

$\mathrm{T}_{3}$ actions are mediated by nuclear $\mathrm{T}_{3}$ receptors (TR) (Yen et al. 2006), which act as ligand-controlled transcription factors. TR $\alpha 1$ is encoded by the TR $\alpha$ gene, which also encodes TR $\alpha 2$, $\operatorname{TR} \Delta \alpha 1$ and $\operatorname{TR} \Delta \alpha 2$ isoforms that do not bind $\mathrm{T}_{3}$ and whose function is largely unknown. TR $\alpha 1$ and TR $\alpha 2$ are expressed in chondrocytes and osteoblasts. TR $\beta 1, \operatorname{TR} \beta 2$ and TR $\beta 3$ are encoded by the TR $\beta$ gene. TR $\beta 1$ is expressed in chondrocytes and osteoblasts. Mice which lack TR $\alpha 1$ and TR $\alpha 2$ display abnormal growth plate architecture and impaired long bone mineralization during post-natal growth (Gauthier et al. 2001) associated with reduced FGFR1 and FGFR3 expression in osteoblasts and chondrocytes (Stevens et al. 2003, Barnard et al. 2005). Introduction of a point mutation into the $T R \alpha$ gene results in the expression of a dominant-negative $\mathrm{TR} \alpha$ protein that inhibits the function of wild-type TRs and causes a similar, but more severe, skeletal phenotype than that observed in $\operatorname{TR} \alpha$ deficient mice (O'Shea et al. 2005). In contrast, mice with the homologous mutation in TR $\beta$ have elevated $\mathrm{TH}$ levels, advanced bone age and short stature with a reduced width of the growth plates affecting both the proliferative and the hypertrophic zones. These features have been interpreted to result from elevated $\mathrm{TH}$ levels acting via intact TR $\alpha 1$ in bone (O'Shea et al. 2003). Nevertheless, a specific role for TR $\beta$ in chondrocytes has also been suggested by studies of the TR $\beta$ selective agonist GC-1 (Freitas et al. 2005). Hypothyroid rats exhibited disorganized chondrocytes columns, reduced hypertrophic chondrocyte differentiation and impaired mineralization. These abnormalities were all rescued by the administration of $\mathrm{T}_{3}$, whereas the $\mathrm{TR} \beta$-selective agonist GC-1 also rescued the chondrocyte differentiation and bone mineralization defects but was unable to restore normal growth plate architecture.

In vivo analysis of mechanisms that account for $\mathrm{T}_{3}$ action in the growth plate is difficult because of the complex interactions between chondrocytes and other cell types and because of the interplay between $\mathrm{T}_{3}$ and other endocrine and paracrine systems, which may be affected by TR genetic modifications. In particular, local concentrations of thyroid hormone can be affected by these mutations: $\operatorname{TR} \beta^{-/-}$mice have been shown not only to have elevated TH levels, but also to have altered expression of de-iodinases in some tissues, including liver (Amma et al. 2001) and cochlea (CamposBarros et al. 2000), thus modifying the local metabolism of $\mathrm{TH}$. The aim of this study was to determine the roles of TR $\alpha$ and $T R \beta$ in $T_{3}$-stimulation of chondrocyte growth, differentiation and maturation, in an in vitro system, which allows a precise control of $\mathrm{TH}$ concentration. For this purpose, we isolated chondrocytes from the ribs of newborn mice. Murine rib chondrocytes cultured in a monolayer maintain a differentiated phenotype of round or polygonal cells that express type II collagen (Lefebvre et al. 1994). Cells differentiate in response to bone morphogenetic protein-2 (BMP-2) (Valcourt et al. 2003, Yagi et al. 2003), but may de-differentiate after several passages if cultured at low density (Lefebvre et al. 1994) or when maintained in the presence of TGF $\beta 1$ (Valcourt et al. 2002). To analyse the roles of TR $\alpha$ and TR $\beta$, we isolated rib chondrocytes from mice, which lack either $\operatorname{TR} \alpha\left(\operatorname{TR} \alpha^{0 / 0}\right.$ mice) (Gauthier et al. 2001) or TR $\beta$ (TR $\beta^{-1-}$ mice) (Gauthier et al. 1999). We measured the expression of TR isotypes at different times of the culture. We monitored the growth of the cultures by measuring the amount of DNA and evaluated the differentiation by measuring the activity of alkaline phosphatase (ALP) and the expression of collagen $\mathrm{X}$.

\section{Materials and Methods}

\section{Animals and cell culture}

Mice were maintained with a ratio of $12 \mathrm{~h}$ light: $12 \mathrm{~h}$ darkness cycle at $22-26{ }^{\circ} \mathrm{C}$ and experiments performed according to requirements of the regional committee of Ethics and the National Committee of Genetics. Homozygous wild type, $\mathrm{TR} \alpha^{0 / 0}$ and $\mathrm{TR} \beta^{-/-}$mice were crossed to obtain homozygous offspring. Neonatal ribs were dissected as described (Lefebvre et al. 1994). Cells were dissociated in $2 \mathrm{mg} / \mathrm{ml}$ protease (Sigma) for $20 \mathrm{~min}$, washed in PBS, incubated in $2 \mathrm{mg} / \mathrm{ml}$ collagenase (Sigma) for $10 \mathrm{~min}$, washed thrice in PBS, and incubated in $2 \mathrm{mg} / \mathrm{ml}$ collagenase for $5 \mathrm{~h}$. The cell pellet was resuspended in DMEM/F12 medium (Gibco, Life Technology) supplemented with 10\% heat-inactivated foetal bovine serum and $2 \mathrm{mM}$ L-glutamine (Gibco), penicillin, streptomycin and gentamycin. Cells were seeded into $75 \mathrm{~cm}^{2}$ flasks at a density of $50000 / \mathrm{cm}^{2}$. Confluent cells were trypsinized and seeded into 96- or 6-well plates at the same density and after $48 \mathrm{~h}$ the medium was replaced by a serum-free medium containing 1:500 ITS (Bio-Whittaker, Walkersville, Cambrex), $1 \mathrm{mg} / \mathrm{ml} \mathrm{BSA}$ and combinations of $10^{-7} \mathrm{M} \mathrm{T}_{3}$ (Sigma) and $100 \mathrm{ng} / \mathrm{ml} \mathrm{BMP-2} \mathrm{(Peprotech,} \mathrm{Tebu).}$

\section{Cell growth and ALP activity}

Cells were harvested at several time points after seeding by washing twice in PBS and freeze-thawing in $50 \mu \mathrm{l}$ Hoechst 33258 solution $(5 \mu \mathrm{g} / \mathrm{ml}$ in $10 \mathrm{mM}$ Tris- $\mathrm{HCl}$, $\mathrm{pH} 8 \cdot 0,150 \mathrm{mM} \mathrm{NaCl}$ and $0.1 \mathrm{mM}$ EDTA). DNA concentration was determined in a Cytofluometer2 multi-well fluorometer (excitation $360 \mathrm{~nm} /$ emission $460 \mathrm{~nm}$ ) compared with a standard curve prepared from calf thymus DNA. ALP activity was determined by freeze-thawing cells in $50 \mu \mathrm{l} 0 \cdot 5 \%$ Triton $\mathrm{X}-100$ and incubating them for $1-30 \mathrm{~min}$ at $37^{\circ} \mathrm{C}$ with $50 \mu \mathrm{l}$ ALP substrate (20 mM p-nitrophenyl phosphate) in alkaline buffer solution (Sigma). Absorbance was determined at $405 \mathrm{~nm}$ in a fluorescence microplate reader (MRX, 
Dynex Technologies) and ALP activity was estimated compared with a standard curve prepared from a p-nitrophenol solution (Sigma), normalized to DNA concentration and expressed as nanomoles/minute per microgram DNA.

Analysis of gene expression by real-time quantitative RT-PCR (qRT-PCR)

RNA was extracted using an RNeasy Kit (Qiagen, Valencia, CA, USA) according to the manufacturer's instructions. Reverse transcription was performed with Superscript II reverse transcriptase (Invitrogen) using 1.25 $\mu \mathrm{g}$ RNA template. One microlitre of tenfold diluted cDNA was used for qRT-PCR, using specific primers (Table 1) to amplify hypoxanthine phosphoribosyl transferase (HPRT), TR $\beta 1$ (Boelen et al. 2005), TR $\alpha 1$ and collagen X (Cormier et al. 2003). Reactions were performed in duplicate for each cDNA using the iQ SYBR Green supermix in an i-cycler IQ thermocycler (Bio-Rad). Quantitation was performed using the Optical System Software (Bio-Rad). Ct values were determined in all amplifications and the mean $\mathrm{Ct}$ value for each duplicate was calculated. For each RNA extraction, the mean $\triangle \mathrm{Ct}$ between the gene of interest and the HPRT gene was calculated. For each series of analyses, the reference sample was derived from untreated wild-type cells at the earliest time point of the culture, or from tissues of untreated wild-type mice. This reference value $\left(\Delta \mathrm{Ct}_{0}\right)$ was subtracted from the $\Delta \mathrm{Ct}$ values of all other samples to give the $\Delta \Delta \mathrm{Ct}$ value; thus, the $\Delta \Delta \mathrm{Ct}$ value of the reference sample was zero. The relative amount of cDNA in each sample was calculated using the formula $\mathrm{RQ}=$ $2^{-\Delta \Delta \mathrm{Ct}}$; thus the quantity of cDNA in the reference sample was 1.

\section{Statistical analysis}

Statistical analysis was performed using unpaired two-tailed Student's $t$ - tests and a $P$ value $<0.05$ was considered significant. These analyses were performed by comparing the data obtained from multiple wells for each experimental condition, within one primary culture. All the results presented in this manuscript have been repeated at least in three independent primary cultures for each genotype.

\section{Results}

Expression of $T R \alpha$ and $T R \beta$ isoforms in rib chondrocytes

Expression of TR isoforms in rib chondrocytes was determined over 21 days in culture by qRT-PCR. In the absence of $T_{3}$, TR $\beta 1$ expression (Fig. 1A) was similar in wild type and $\mathrm{TR} \alpha^{0 / 0}$ cells and did not vary significantly with time, other than a $50 \%$ decrease at day 12 compared with day 6 in wild-type cells. In the presence of $T_{3}$, TR $\beta 1$ expression increased significantly at days 12 and 21 in the wild-type cells and at days 6 and 21 in TR $\alpha^{0 / 0}$ cells, as compared with the control untreated cells. TR $\beta 1$ expression in the presence of $\mathrm{T}_{3}$ did not differ between wild type and $\mathrm{TR} \alpha^{0 / 0}$ cells at any time of the culture. In wild-type chondrocytes in the absence of $\mathrm{T}_{3}$, TR $\alpha 1$ expression (Fig. 1B) remained constant until day 21. In $\mathrm{T}_{3}$-treated cells, TR $\alpha 1$ expression tended to be lower at day 6 and significantly decreased at days 12 and 21 compared with the control untreated cells. In untreated $\operatorname{TR} \beta^{-/-}$ chondrocytes, TR $\alpha 1$ expression was lower than in untreated wild-type cells at all times. $T_{3}$ decreased TR $\alpha 1$ expression at day 6 but did not have any effect at days 12 and 21 .

$T_{3}$ inhibits growth of wild-type and TR $\alpha$-deficient, but not $T R \beta$-deficient rib chondrocytes in the presence of BMP-2

When wild-type rib chondrocytes were grown in $10 \%$ foetal bovine serum, cell numbers increased during the first 7 days of culture but remained stable until day 21 (Fig. 2A). In serum-free medium, cell numbers declined between day 7 and day 14 , but remained stable until day $21 . \mathrm{T}_{3}$ treatment had no effect on cell growth in serum-free medium. In contrast, treatment with BMP-2 increased cell number by $40-100 \%$ at days 7,14 and 21 (four separate cultures from four different litters, eight wells per treatment for each culture). $T_{3}$ significantly decreased the number of cells measured in the presence of BMP-2 at days 7, 14 and 21 by $20-40 \%$ in four separate experiments. Thus, $\mathrm{T}_{3}$ inhibits BMP-2-induced growth of wild-type mouse rib chondrocytes. Chondrocytes from $\mathrm{TR} \alpha^{0 / 0}$ mice cultured in $10 \%$ serum or in the absence of $\mathrm{T}_{3}$ displayed a similar pattern of growth as wild-type cells (Fig. 2B). Treatment with $\mathrm{T}_{3}$ alone had no significant effect on cell growth. BMP-2 stimulated cell growth by $40-120 \%$ (three separate experiments, eight wells per treatment for each culture), and $T_{3}$ reduced the cell number obtained in the presence of BMP-2 by $20-30 \%$ (three separate experiments).

Table 1 DNA sequences of primers used in real-time PCR

Upstream primer

Gene products
HPRT
TR $\alpha 1$
TR $\beta 1$
CollagenX

5' GCAGTACAGCCCCAAAATGG 3'

5' CATCTTTGAACTGGGCAAGT 3'

5' CACCTGGATCCTGACGATGT $3^{\prime}$

5' CAAACGGCCTCTACTCCTCTGA 3'
Downstream primer

5' AACAAAGTCTGGCCTGTATCCAA 3'

5' CTGAGGCTTTAGACTTCCTGATC $3^{\prime}$

5' ACAGGTGATGCAGCGATAGT 3'

5' CGATGGAATTGGGTGGAAAG $3^{\prime}$ 

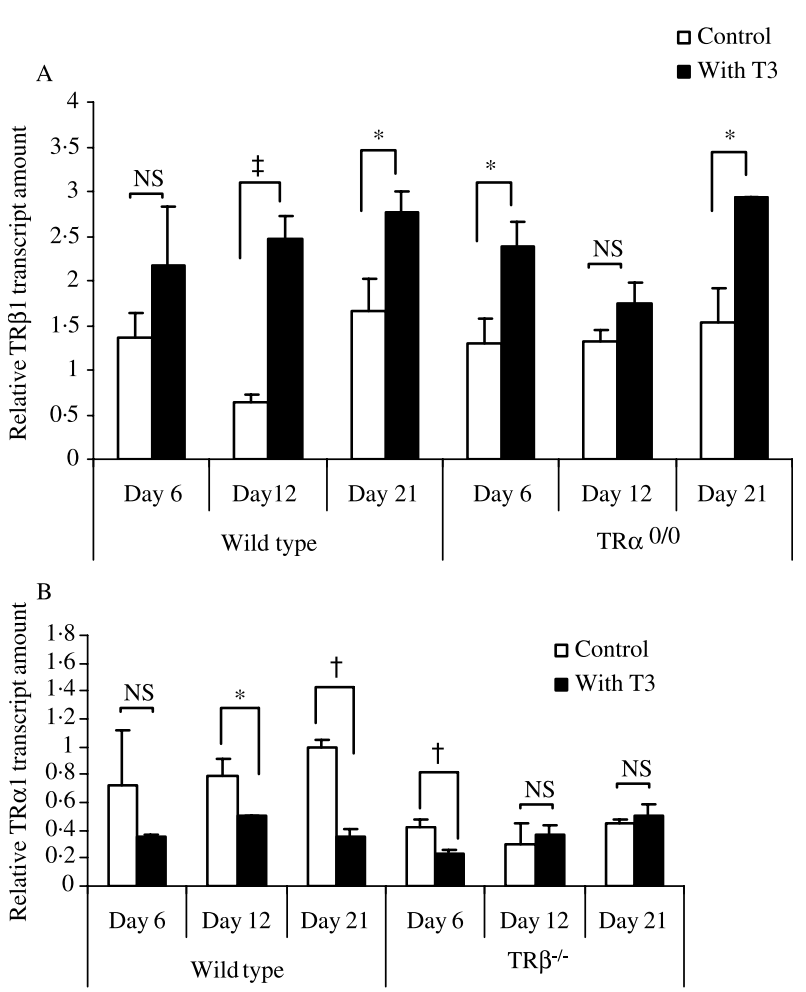

Figure 1 Expression of TR isoforms in rib chondrocytes. (A) TR $\beta 1$ mRNA concentrations normalized to HPRT, in primary wild-type and $\mathrm{TR}^{\mathrm{O} / 0}$ mouse rib chondrocytes cultured for 6,12 and 21 days in the absence or presence of $10^{-7} \mathrm{M} \mathrm{T}_{3}$. Results are shown as mean \pm s.E.M. $n \geq 3$ for all conditions except for $T_{3}$-treated $T R \alpha^{0 / 0}$ cells at day $21(n=2)$. (B) Expression of TR $\alpha 1-m R N A$ normalized to HPRT in TR $\beta^{-1-}$ chondrocytes cultured for 6,12 and 21 days in the absence or presence of $10^{-7} \mathrm{M} \mathrm{T}_{3}$. Results are shown as mean \pm S.E.M. $n \geq 2$ for all conditions. Data were analysed by two-tailed Student's $t$-test. NS, not significant; $* P<0 \cdot 001$; ${ }^{+} P<0 \cdot 05 ;{ }^{\ddagger} P<0 \cdot 01$.

In $10 \%$ serum and in the absence of $\mathrm{T}_{3}$, chondrocytes from $\operatorname{TR} \beta^{-/-}$mice had a similar growth pattern to that observed in wild-type cells (Fig. 2C). $\mathrm{T}_{3}$ did not modify the growth of TR $\beta^{-/-}$chondrocytes. BMP-2 stimulated chondrocyte growth by $25-100 \%$, but $\mathrm{T}_{3}$ did not significantly affect this stimulation in three separate experiments (eight wells per treatment for each culture).

$T_{3}$ stimulates differentiation of wild type and $T R \alpha$-deficient, but not TR $\beta$-deficient rib chondrocytes

Chondrocyte differentiation was monitored by measuring ALP activity at days 14 and 21 (Fig. 3), and collagen X expression at days 6,12 and 21 (Fig. 4). When wild-type chondrocytes were cultured in the absence of $\mathrm{T}_{3}$, ALP activity increased by fourfold between day 14 and day 21 (Fig. 3A). ALP activity was increased five- and threefold at days 14 and 21 respectively, following $T_{3}$ treatment. A two- to fivefold stimulation of ALP activity by $\mathrm{T}_{3}$ was observed at day 21 in five separate experiments. Treatment with BMP-2 elicited a
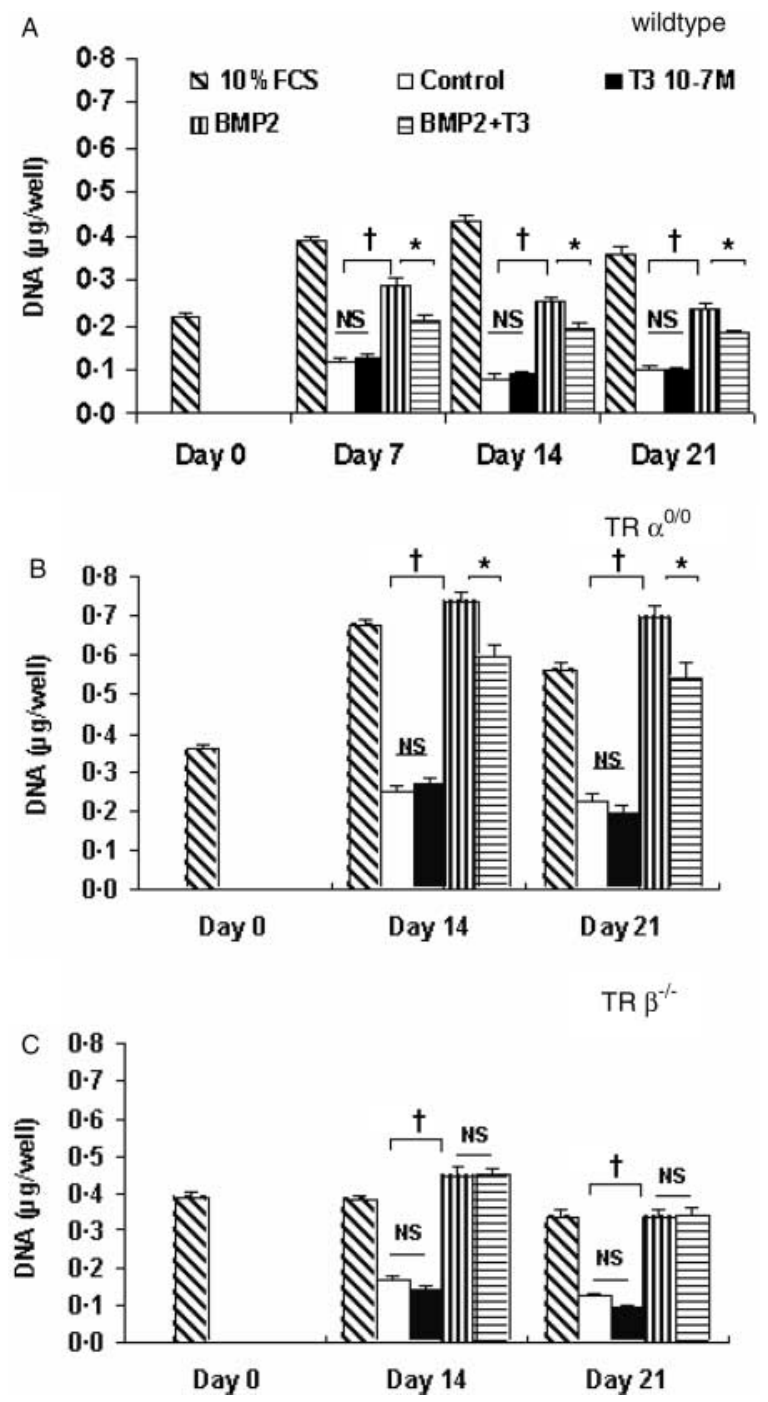

Figure 2 Effect of $\mathrm{T}_{3}$ and $\mathrm{BMP}-2$ on growth of primary rib chondrocytes. Results are expressed as micrograms DNA per well. Cells were seeded on day $0\left(50000 \mathrm{cells} / \mathrm{cm}^{2}\right)$ and maintained in the absence or presence of $\mathrm{T}_{3}(100 \mathrm{nM}) \pm \mathrm{BMP}-2(100 \mathrm{ng} / \mathrm{ml})$ for 21 days. All experiments were performed four times (four independent cultures). For each culture, eight wells per condition were seeded. The graphs show a single typical experiment for each genotype. The bars indicate mean \pm S.E.M. Results were analysed by two-tailed Student's $t$-test. NS, not significant; ${ }^{*} P<0 \cdot 001$; ${ }^{+} P<0 \cdot 01$. (A) Wild-type chondrocytes. (B) TR $\alpha^{0 / 0}$ chondrocytes. (C) $\mathrm{TR}^{-i-}$ chondrocytes. Hatched bars, $10 \%$ FCS; white bars, control, serum-free medium; black bars, serum-free medium with $\mathrm{T}_{3}\left(10^{-7} \mathrm{M}\right)$; vertically hatched bars, serum-free medium with BMP-2 $(100 \mathrm{ng} / \mathrm{ml})$, horizontally hatched bars, serum-free medium with $\mathrm{T}_{3}\left(10^{-7} \mathrm{M}\right)$ and BMP-2 $(100 \mathrm{ng} / \mathrm{ml})$.

nine- and a fivefold increase in ALP activity at days 14 and 21 respectively, compared with untreated cells. A further 2- to $2 \cdot 5$-fold activation was observed when cells were treated with both BMP-2 and $\mathrm{T}_{3}$. In $\mathrm{TR} \alpha^{0 / 0}$ chondrocytes, basal ALP activity was stable between days 14 and $21 . \mathrm{T}_{3}$ increased ALP 

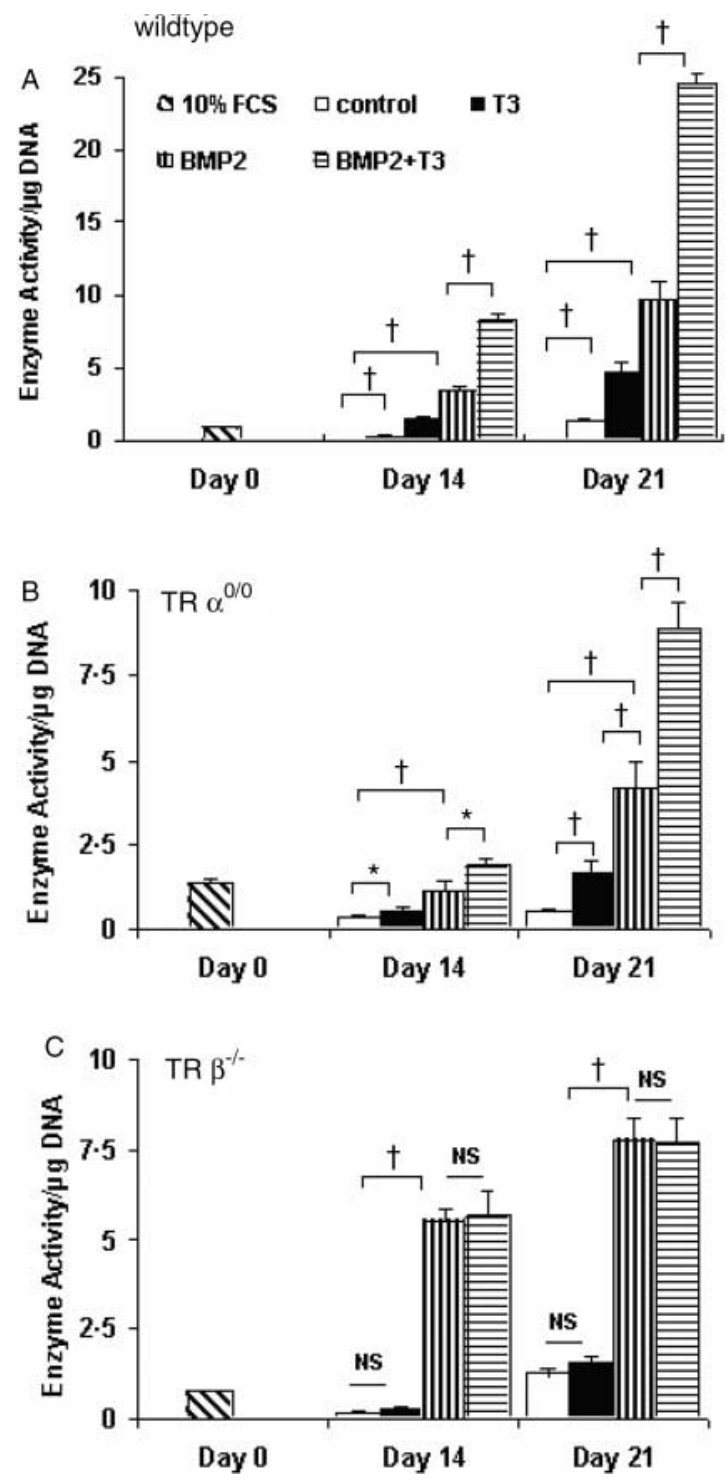

Figure 3 Effect of $\mathrm{T}_{3}$ on alkaline phosphatase activity in primary rib chondrocytes. Chondrocytes were cultured for 21 days in the absence or presence of $10^{-7} \mathrm{M} \mathrm{T}_{3} \pm 100 \mathrm{ng} / \mathrm{ml} \mathrm{BMP}-2$. Alkaline phosphatase activity is expressed as nanomoles of substrate hydrolysed per minute per micrograms of DNA \pm S.E.M. ( $n=4$ experiments, eight wells per condition). Results were analysed by two-tailed Student's $t$-test. NS, not significant. ${ }^{*} P<0 \cdot 001 ;{ }^{+} P<0 \cdot 01$. (A) Wild-type chondrocytes. (B) $\mathrm{TR} \alpha^{\mathrm{O} / 0}$ chondrocytes. (C) TR $\beta^{-1-}$ chondrocytes. Hatched bars, $10 \%$ FCS; white bars, control, serum-free medium; black bars, serum-free medium with $\mathrm{T}_{3}\left(10^{-7} \mathrm{M}\right)$; vertically hatched bars, serum-free medium with BMP-2 $(100 \mathrm{ng} / \mathrm{ml})$, horizontally hatched bars, serum-free medium with $\mathrm{T}_{3}\left(10^{-7} \mathrm{M}\right)$ and BMP-2 (100 ng/ml).

activity by $30 \%$ at day 14 and by $2 \cdot 5$-fold at day 21 (Fig. 3B). In four separate experiments, ALP activity was stimulated by $\mathrm{T}_{3}$ by two- to fivefold in $\mathrm{TR} \alpha^{0 / 0}$ chondrocytes. BMP-2 stimulated ALP activity at days 14 and 21 by two- and fourfold respectively. $\mathrm{T}_{3}$ further increased this activity by $40 \%$ at day
14 and twofold at day 21. Notably, ALP activity was lower in $\mathrm{TR} \alpha^{0 / 0}$ chondrocytes than wild-type cells in all cultures. In untreated TR $\beta^{-\prime-}$ chondrocytes, ALP activity displayed a similar pattern as in wild-type cells, with an increase between days 14 and 21. However, $T_{3}$ failed to stimulate ALP activity in TR $\beta^{-/-}$chondrocytes (Fig. 3C). In contrast, BMP-2 stimulated ALP activity 22 -fold at day 14 and eightfold at day 21 , indicating that $\operatorname{TR} \beta^{-1-}$ chondrocytes retain their differentiation capacity. $T_{3}$ had no additional effect on ALP activity in the presence of BMP-2.

Expression of collagen $\mathrm{X}$, another specific marker of chondrocyte differentiation, was also determined (Fig. 4). Basal expression of collagen $\mathrm{X}$ in the absence of $\mathrm{T}_{3}$ was similar in wild type, $\operatorname{TR} \alpha^{0 / 0}$ and $\operatorname{TR} \beta^{-/-}$chondrocytes throughout the 21-day period of culture. Collagen $\mathrm{X}$ expression was increased by $\mathrm{T}_{3}$ at all times in wild type and $\mathrm{TR} \alpha^{0 / 0}$ chondrocytes, but this stimulation was less in $\mathrm{TR} \alpha^{0 / 0}$ cells at day 6 compared with wild type. In contrast, $\mathrm{T}_{3}$ failed to stimulate collagen $\mathrm{X}$ expression in $\mathrm{TR} \beta^{-/-}$chondrocytes.

\section{Discussion}

Chondrocytes are sensitive to thyroid hormones in vivo and in vitro (Nilsson et al. 2005). In vitro, $\mathrm{T}_{3}$ inhibits cell proliferation but accelerates hypertrophic chondrocyte differentiation; however, the mechanisms responsible for these effects are poorly understood. In order to understand the mechanisms of $\mathrm{T}_{3}$ action in chondrocytes, it is important to define which TR mediates its biological effects, and thus we investigated chondrocyte proliferation and differentiation in primary cells obtained from $\operatorname{TR} \alpha$ and $\operatorname{TR} \beta$ knockout mice. Inhibition of chondrocyte proliferation by $\mathrm{T}_{3}$ has been demonstrated in several cell culture systems, including epiphyseal chondrocyte monolayer (Ishikawa et al. 1998) and three-dimensional cultures (Ballock et al. 2000, Robson et al. 2000). When mouse rib chondrocytes were cultured in serum-free medium, cell proliferation declined within the first $48 \mathrm{~h}$ (data not shown) before reaching a plateau. Addition of $\mathrm{T}_{3}$ had no effect on cell growth in serum-free medium, which is not surprising because $T_{3}$ has not been reported to exert effects on quiescent chondrocyte cultures, although it is has been shown to inhibit expansion of proliferating chondrocyte cultures (Ballock et al. 2000, Robson et al. 2000). In contrast and consistent with studies showing that BMP-2 stimulates mouse growth plate chondrocyte proliferation in vivo (Minina et al. 2001), BMP-2 not only prevented cell loss but also stimulated growth of primary rib chondrocytes. Importantly, $\mathrm{T}_{3}$ prevented the BMP-2-induced increase in cell number, indicating that $\mathrm{T}_{3}$ inhibits BMP-2-stimulated growth of mouse rib chondrocytes. We also demonstrated that growth of $\operatorname{TR} \alpha-$ and $\operatorname{TR} \beta-$ deficient chondrocytes in serum-free medium and in the presence of BMP-2 was similar to the growth of wild-type cells, suggesting that TRs do not play a role in $\mathrm{T}_{3}$-independent chondrocyte growth. As observed in wild-type cells, $\mathrm{T}_{3}$ had no effect on the growth of $\operatorname{TR} \alpha^{0 / 0}$ or TR $\beta^{-/-}$cells in basal medium. Addition of $\mathrm{T}_{3}$ to BMP-2-treated cultures impaired 


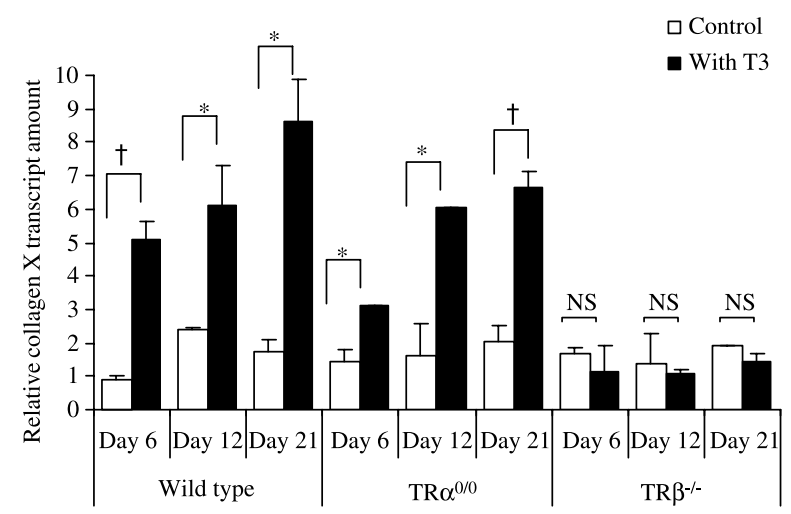

Figure 4 Effect of $T_{3}$ on collagen $X$ mRNA expression in rib chondrocytes. Wild type, $\operatorname{TR} \alpha^{0 / 0}$ and TR $\beta^{-1-}$ chondrocytes were grown for 6,12 and 21 days in the absence (white bars) or presence (black bars) of $10^{-7} \mathrm{M} \mathrm{T}_{3}$-ColX mRNA was normalized to the concentration of HPRT mRNA. Data are expressed as mean \pm S.E.M. ( $n=2$ each condition). Results were analysed by two-tailed Student's $t$-test. NS, not significant. ${ }^{*} P<0 \cdot 05 ;{ }^{\dagger} P<0 \cdot 01$.

growth of $\mathrm{TR} \alpha^{0 / 0}$ chondrocytes, as observed with wild-type cells, but had no effect on BMP-2-treated $\operatorname{TR} \beta^{-/-}$ chondrocytes. These data suggest that TR $\beta 1$ mediates the inhibitory action of $\mathrm{T}_{3}$ on the BMP-2-stimulated proliferation of mouse rib chondrocytes.

$\mathrm{T}_{3}$ has been shown to stimulate terminal differentiation of chondrocytes in a variety of systems (Alini et al. 1996, Leboy et al. 1997, Ishikawa et al. 1998, Rosenthal \& Henry 1999, Robson et al. 2000, Stevens et al. 2000, Okubo \& Reddi 2003). In particular, $T_{3}$ stimulates ALP activity and increases the expression of collagen $\mathrm{X}$ in these models. When mouse rib chondrocytes were cultured for 21 days in serum-free medium in the absence of $\mathrm{T}_{3}, \mathrm{ALP}$ activity and collagen $\mathrm{X}$ expression were similar to the levels at the onset of culture, indicating a lack of hypertrophic differentiation. In contrast, in the presence of $\mathrm{T}_{3}$, ALP activity increased rapidly and collagen $\mathrm{X}$ expression was stimulated at all time points indicating that $T_{3}$ stimulates differentiation of primary mouse rib chondrocytes in monolayer cultures.

ALP activity in $\mathrm{TR} \alpha^{0 / 0}$ chondrocytes was consistently lower than in wild-type cells in all culture conditions; however, the amplitude of responses to $\mathrm{T}_{3}, \mathrm{BMP}-2$ and both agents was similar in wild type and TR $\alpha$-deficient cells. Collagen $\mathrm{X}$ expression was also stimulated by $\mathrm{T}_{3}$ to a similar degree in both $\mathrm{TR} \alpha^{0 / 0}$ and wild-type chondrocytes. In contrast, $\mathrm{T}_{3}$-stimulation of ALP and collagen $\mathrm{X}$ was abolished in $\operatorname{TR} \beta^{-/-}$ chondrocytes. Explanations for this discrepancy include an absence or low proportion of chondrocyte precursors within the ribs of $\operatorname{TR} \beta^{-1-}$ mice, or an impaired intrinsic inability of $\mathrm{TR} \beta^{-1-}$ cells to differentiate into mature chondrocytes. However, BMP-2 stimulated the differentiation of $\operatorname{TR} \beta^{-/-}$ cells to the same extent as in wild type and TR $\alpha$-deficient cells, indicating that TR $\beta$-deficient cells have the intrinsic capacity to differentiate into mature chondrocytes. Furthermore, whereas $\mathrm{T}_{3}$ could enhance the ALP response of wild type and $\mathrm{TR} \alpha^{0 / 0}$ chondrocytes to BMP-2, it had no effect in BMP-2-treated TR $\beta^{-/-}$cells. All these data suggest that the $\mathrm{T}_{3}$-dependent differentiation pathway is selectively impaired in TR $\beta$-deficient cells.

The predominant role of TR $\beta 1$ in the mediation of $\mathrm{T}_{3}$ action in mouse rib chondrocytes is consistent with the pattern of expression of TR isoforms during differentiation of wild type and TR-deficient cells. In wild-type cells, $\mathrm{T}_{3}$ increased expression of TR $\beta 1$ and decreased expression of TR $\alpha 1$. This differential regulation of TR-isotype expression by $T_{3}$ suggests TR $\beta 1$ as the main mediator of $\mathrm{T}_{3}$ action in these cells. The observations that, following treatment with $\mathrm{T}_{3}$, increased TR $\beta 1$ expression is preserved in TR $\alpha$-deficient cells, whereas the decrease in TR $\alpha 1$ expression is attenuated in TR $\beta$-deficient cells also support a key role for TR $\beta 1$. Our observations do not exclude the possibility that in wild-type chondrocytes, both TRs can mediate $T_{3}$ action and that TR $\beta 1$ can substitute for $\mathrm{TR} \alpha 1$ in $\mathrm{TR} \alpha^{0 / 0}$ cells, whereas TR $\alpha 1$ cannot substitute for TR $\beta 1$ in TR $\beta^{-/-}$cells. Indeed, in the absence of $\mathrm{T}_{3}$, the level of expression of TR $\alpha 1$ was lower in $\operatorname{TR} \beta^{-/-}$than in wild-type cells. One explanation for this low amount of TR $\alpha 1$ in $\operatorname{TR} \beta$ deficient cells is that TR $\beta 1$ as an aporeceptor positively regulates the expression of TR $\alpha 1$. The absence of TR $\beta$ would therefore decrease the expression of TR $\alpha 1$ and diminish the response to $\mathrm{T}_{3}$. Consequently, it is possible that $\mathrm{TR} \alpha 1$ is active in wild-type cells but, because less abundant, unable to mediate $T_{3}$ action in $\mathrm{TR} \beta^{-/-}$cells. In TR $\alpha$-deficient cells, the response to $\mathrm{T}_{3}$ may be mediated by TR $\beta 1$, however, no compensatory overexpression of this isotype was observed in $\operatorname{TR} \alpha^{0 / 0}$ cells. Although it is not possible to exclude that TR $\alpha 1$ is involved in $T_{3}$ action in wild-type chondrocytes, upregulation of TR $\beta 1$ and the downregulation of TR $\alpha 1$ by $T_{3}$ in these cells are more consistent with a major role of TR $\beta 1$. Such a key role of TR $\beta 1$ in the modulation of chondrocyte differentiation by $T_{3}$ is supported by in vivo studies using the $\operatorname{TR} \beta$-selective agonist 
GC-1 (Freitas et al. 2005). In these studies, young hypothyroid rats displayed altered organization of chondrocyte columns within the growth plate with impaired hypertrophic differentiation, as assessed by the decreased size of the hypertrophic zone and reduced expression of collagen X. GC-1, like $T_{3}$, restored normal morphometric parameters of the growth plate and normal expression of collagen $\mathrm{X}$, strongly suggesting that TR $\beta 1$ mediates the effect of $\mathrm{T}_{3}$ on chondrocyte differentiation. These findings are consistent with an important role for TR $\beta 1$ in the control of chondrocyte differentiation and, thus, the role of TR $\alpha 1$ in chondrocyte biology remains to be elucidated. In hypothyroid rats, $\mathrm{T}_{3}$, but not the TR $\beta$-selective agonist GC- 1 , restored normal organization of the growth plate, suggesting that $\mathrm{TR} \alpha 1$ mediates the effects of $\mathrm{T}_{3}$ on the spatial organization of chondrocytes (Freitas et al. 2005). However, our findings using rib chondrocytes in monolayer cultures did not demonstrate a major role for TR $\alpha$ in the regulation of cell proliferation and differentiation. It is possible that, in vivo or in a three-dimensional environment, TR $\alpha 1$ is the key mediator of $\mathrm{T}_{3}$ action, whereas in monolayer cultures, TR $\beta 1$ becomes predominant. Nonetheless, in $\mathrm{TR} \alpha^{0 / 0}$-chondrocytes, ALP activity was blunted compared with wild-type cells, raising the possibility that $\operatorname{TR} \alpha$ may be a permissive factor that facilitates chondrocyte differentiation. The importance of $\operatorname{TR} \alpha$ is further suggested by the growth plate phenotype of mice lacking the TR $\alpha$ gene (Fraichard et al. 1997, Gauthier et al. 2001) or expressing a dominant negative TR $\alpha 1$ isoform (O'Shea et al. 2005). These mice have disorganized chondrocyte columns and reduced width of the hypertrophic zone. However, they also have mild hypothyroxinemia (Macchia et al. 2001, Weiss et al. 2002), raising the possibility that the observed phenotype results from reduced local $\mathrm{TH}$ availability.

Altogether, our data are consistent with the observations from TR-knockout and knock-in mice, and suggest that TR $\beta 1$ mediates important $T_{3}$ effects on hypertrophic chondrocyte terminal differentiation, whereas TR $\alpha 1$ is likely to be involved in the control of cellular and molecular interactions that are important for the three-dimensional organization of growth plate cartilage and the initiation of chondrocyte differentiation. These findings may have important applications for the potential use of $\mathrm{T}_{3}$ analogues as therapeutic agents for the treatment of bone and articular cartilage lesions.

\section{Acknowledgements}

This work was supported by Centre National de la Recherche Scientifique (CNRS), by Institut National de la Santé et de la Recherche Médicale (INSERM), and by grant ACI no. 0220601 of the French Ministry of Research. The authors declare that there is no conflict of interest that would prejudice the impartiality of this scientific work.

\section{References}

Alini M, Kofsky Y, Wu W, Pidoux I \& Poole AR 1996 In serum-free culture thyroid hormones can induce full expression of chondrocyte hypertrophy leading to matrix calcification. Journal of Bone and Mineral Research 11 105-113.

Amma LL, Campos-Barros A, Wang Z, Vennstrom B \& Forrest D 2001 Distinct tissue-specific roles for thyroid hormone receptors beta and alpha1 in regulation of type 1 deiodinase expression. Molecular Endocrinology 15 467-475.

Ballock RT \& Reddi AH 1994 Thyroxine is the serum factor that regulates morphogenesis of columnar cartilage from isolated chondrocytes in chemically defined medium. Journal of Cell Biology 126 1311-1318.

Ballock RT, Zhou X, Mink LM, Chen DH, Mita BC \& Stewart MC 2000 Expression of cyclin-dependent kinase inhibitors in epiphyseal chondrocytes induced to terminally differentiate with thyroid hormone. Endocrinology 141 4552-4557.

Barnard JC, Williams AJ, Rabier B, Chassande O, Samarut J, Cheng SY, Bassett JH \& Williams GR 2005 Thyroid hormones regulate fibroblast growth factor receptor signaling during chondrogenesis. Endocrinology 146 $5568-5580$

Bassett JH \& Williams GR 2003 The molecular actions of thyroid hormone in bone. Trends in Endocrinology and Metabolism 14 356-364.

Boelen A, Kwakkel J, Alkemade A, Renckens R, Kaptein E, Kuiper G, Wiersinga WM \& Visser TJ 2005 Induction of type 3 deiodinase activity in inflammatory cells of mice with chronic local inflammation. Endocrinology 146 5128-5134.

Bohme K, Conscience-Egli M, Tschan T, Winterhalter KH \& Bruckner P 1992 Induction of proliferation or hypertrophy of chondrocytes in serumfree culture: the role of insulin-like growth factor-I, insulin, or thyroxine. Journal of Cell Biology 116 1035-1042.

Bohme K, Winterhalter KH \& Bruckner P 1995 Terminal differentiation of chondrocytes in culture is a spontaneous process and is arrested by transforming growth factor-beta 2 and basic fibroblast growth factor in synergy. Experimental Cell Research 216 191-198.

Campos-Barros A, Amma LL, Faris JS, Shailam R, Kelley MW \& Forrest D 2000 Type 2 iodothyronine deiodinase expression in the cochlea before the onset of hearing. PNAS 97 1287-1292.

Cormier SA, Mello MA \& Kappen C 2003 Normal proliferation and differentiation of Hoxc-8 transgenic chondrocytes in vitro. BMC Developmental Biology 34.

Fraichard A, Chassande O, Plateroti M, Roux JP, Trouillas J, Dehay C, Legrand C, Gauthier K, Kedinger M, Malaval L et al. 1997 The T3R alpha gene encoding a thyroid hormone receptor is essential for post-natal development and thyroid hormone production. EMBO Journal 16 4412-4420.

Freitas FR, Capelo LP, O'Shea PJ, Jorgetti V, Moriscot AS, Scanlan TS, Williams GR, Zorn TM \& Gouveia CH 2005 The thyroid hormone receptor beta-specific agonist GC-1 selectively affects the bone development of hypothyroid rats. Journal of Bone and Mineral Research 20 294-304.

Gauthier K, Chassande O, Plateroti M, Roux JP, Legrand C, Pain B, Rousset B, Weiss R, Trouillas J \& Samarut J 1999 Different functions for the thyroid hormone receptors TRalpha and TRbeta in the control of thyroid hormone production and post-natal development. EMBO Journal 18 623-631.

Gauthier K, Plateroti M, Harvey CB, Williams GR, Weiss RE, Refetoff S, Willott JF, Sundin V, Roux JP, Malaval L et al. 2001 Genetic analysis reveals different functions for the products of the thyroid hormone receptor alpha locus. Molecular and Cellular Biology 21 4748-4760.

Gerber HP \& Ferrara N 2000 Angiogenesis and bone growth. Trends in Cardiovascular Medicine 10 223-228.

Goldring MB, Tsuchimochi K \& Ijiri K 2006 The control of chondrogenesis. Journal of Cellular Biochemistry 97 33-44.

Ishikawa Y, Genge BR, Wuthier RE \& Wu LN 1998 Thyroid hormone inhibits growth and stimulates terminal differentiation of epiphyseal growth plate chondrocytes. Journal of Bone and Mineral Research 13 1398-1411. 
Leboy PS, Sullivan TA, Nooreyazdan M \& Venezian RA 1997 Rapid chondrocyte maturation by serum-free culture with BMP-2 and ascorbic acid. Journal of Cellular Biochemistry 66 394-403.

Lefebvre V, Garofalo S, Zhou G, Metsaranta M, Vuorio E \& De Crombrugghe B 1994 Characterization of primary cultures of chondrocytes from type II collagen/beta-galactosidase transgenic mice. Matrix Biology 14 329-335.

Lewinson D, Bialik GM \& Hochberg Z 1994 Differential effects of hypothyroidism on the cartilage and the osteogenic process in the mandibular condyle: recovery by growth hormone and thyroxine. Endocrinology 135 1504-1510.

Macchia PE, Takeuchi Y, Kawai T, Cua K, Gauthier K, Chassande O, Seo H, Hayashi Y, Samarut J, Murata Y et al. 2001 Increased sensitivity to thyroid hormone in mice with complete deficiency of thyroid hormone receptor alpha. PNAS 98 349-354.

Minina E, Wenzel HM, Kreschel C, Karp S, Gaffield W, McMahon AP \& Vortkamp A 2001 BMP and Ihh/PTHrP signaling interact to coordinate chondrocyte proliferation and differentiation. Development 128 4523-4534.

Miura M, Tanaka K, Komatsu Y, Suda M, Yasoda A, Sakuma Y, Ozasa A \& Nakao K 2002 Thyroid hormones promote chondrocyte differentiation in mouse ATDC5 cells and stimulate endochondral ossification in fetal mouse tibias through iodothyronine deiodinases in the growth plate. Journal of Bone and Mineral Research 17 443-454.

Nilsson O, Marino R, De Luca F, Phillip M \& Baron J 2005 Endocrine regulation of the growth plate. Hormone Research 64 157-165.

O'Shea PJ, Harvey CB, Suzuki H, Kaneshige M, Kaneshige K, Cheng SY \& Williams GR 2003 A thyrotoxic skeletal phenotype of advanced bone formation in mice with resistance to thyroid hormone. Molecular Endocrinology 17 1410-1424.

O'Shea PJ, Bassett JH, Sriskantharajah S, Ying H, Cheng SY \& Williams GR 2005 Contrasting skeletal phenotypes in mice with an identical mutation targeted to thyroid hormone receptor alpha1 or beta. Molecular Endocrinology 19 3045-3059.

Ohlsson C, Nilsson A, Isaksson O, Bentham J \& Lindahl A 1992 Effects of triiodothyronine and insulin-like growth factor-I (IGF-I) on alkaline phosphatase activity, $\left[{ }^{3} \mathrm{H}\right]$ thymidine incorporation and IGF-I receptor mRNA in cultured rat epiphyseal chondrocytes. Journal of Endocrinology 135 115-123.

Okubo Y \& Reddi AH 2003 Thyroxine downregulates Sox9 and promotes chondrocyte hypertrophy. Biochemical and Biophysical Research Communications 306 186-190.

Quarto R, Campanile G, Cancedda R \& Dozin B 1992 Thyroid hormone, insulin, and glucocorticoids are sufficient to support chondrocyte differentiation to hypertrophy: a serum-free analysis. Journal of Cell Biology 119 989-995.
Robson H, Siebler T, Stevens DA, Shalet SM \& Williams GR 2000 Thyroid hormone acts directly on growth plate chondrocytes to promote hypertrophic differentiation and inhibit clonal expansion and cell proliferation. Endocrinology 141 3887-3897.

Rosenthal AK \& Henry LA 1999 Thyroid hormones induce features of the hypertrophic phenotype and stimulate correlates of CPPD crystal formation in articular chondrocytes. Journal of Rheumatology 26 395-401.

Stevens DA, Hasserjian RP, Robson H, Siebler T, Shalet SM \& Williams GR 2000 Thyroid hormones regulate hypertrophic chondrocyte differentiation and expression of parathyroid hormone-related peptide and its receptor during endochondral bone formation. Journal of Bone and Mineral Research 15 2431-2442.

Stevens DA, Harvey CB, Scott AJ, O'Shea PJ, Barnard JC, Williams AJ, Brady G, Samarut J, Chassande O \& Williams GR 2003 Thyroid hormone activates fibroblast growth factor receptor-1 in bone. Molecular Endocrinology 17 $1751-1766$.

Valcourt U, Gouttenoire J, Moustakas A, Herbage D \& Mallein-Gerin F 2002 Functions of transforming growth factor-beta family type I receptors and Smad proteins in the hypertrophic maturation and osteoblastic differentiation of chondrocytes. Journal of Biological Chemistry 277 33545-33558.

Valcourt U, Gouttenoire J, Aubert-Foucher E, Herbage D \& Mallein-Gerin F 2003 Alternative splicing of type II procollagen pre-mRNA in chondrocytes is oppositely regulated by BMP-2 and TGF-beta1. FEBS Letters 545 115-119.

Wakita R, Izumi T \& Itoman M 1998 Thyroid hormone-induced chondrocyte terminal differentiation in rat femur organ culture. Cell and Tissue Research 293 357-364.

Weiss RE, Chassande O, Koo EK, Macchia PE, Cua K, Samarut J \& Refetoff S 2002 Thyroid function and effect of aging in combined hetero/homozygous mice deficient in thyroid hormone receptors alpha and beta genes. Journal of Endocrinology 172 177-185.

Yagi K, Tsuji K, Nifuji A, Shinomiya K, Nakashima K, DeCrombrugghe B \& Noda M 2003 Bone morphogenetic protein-2 enhances osterix gene expression in chondrocytes. Journal of Cellular Biochemistry 88 1077-1083.

Yen PM, Ando S, Feng X, Liu Y, Maruvada P \& Xia X 2006 Thyroid hormone action at the cellular, genomic and target gene levels. Molecular and Cellular Endocrinology 246 121-127.

Received 27 February 2006

Received in final form 4 July 2006

Accepted 6 July 2006 